\title{
Legal structure of apartments: experience of doctrinal understanding and analysis of legislative decisions
}

\author{
Dmitry A. Formakidov* \\ Department of Civil Law, Perm State National Research University, 15 Bukireva St., 614990, Perm, Russia
}

\begin{abstract}
The paper is devoted to theoretical and practical problems of determining the legal status of apartments according to the current Russian legislation. The relevance of the study is bound to the introduction of the draft legislation on the regulation of relations, construction and use of apartments in multiuse buildings at the end of April 2021 by the State Duma of the Russian Federation. The paper provides a comprehensive analysis of the views in the legal literature regarding the legal structure of apartments. A comparative legal analysis of apartments and residential premises was carried out taking into account the characteristics and types of the latter. It was concluded that apartments are classified as nonresidential premises. The proposed legislative regulation of relations arising in the process of erection and subsequent operation of multiuse buildings and premises located in such buildings used for the accommodation of citizens is analyzed. Conclusions were drawn on the imperfection of the existing legal regulation and the disadvantages of the proposed draft legislation.
\end{abstract}

\section{Introduction}

The pace of economic development of the Russian state in the post-Soviet period, the transition from a planned to market economy, the recognition of the right of private ownership of real estate allowed Russian citizens independently improving their housing conditions. At the same time, many citizens were not just in the right, but also forced to improve their housing conditions on their own.

The Russian Federation as a developed social state has elevated the right of citizens to housing to the rank of constitutional. Article 40 of the Constitution recognizes the right of every citizen to housing. Besides, according to article 40, part 2 of the Constitution, the authorities promote housing construction and create conditions for the realization of the right to housing. Among other conditions for creating a favorable environment for the realization of the right to housing, the state systematically affects the reduction of mortgage rates, supports "young families", carries out other measures aimed at creating an affordable, attractive market for residential real estate in the country, recognizing that the need for housing is among the key, basic needs of any citizen.

These circumstances entailed the rapid development of housing construction. In each region of modern Russia, housing construction is one of the priority tasks of regional authorities.

At the same time, in recent years, the real estate market in the country has been flooded with objects sold by developers as "apartments" or "residential apartments". Indeed, first of all, the problem of apartments affected large cities.

Unscrupulous developers are actively creating buildings, including objects under the beautiful mysterious name of apartments, and citizens, guided by various reasons, actively acquire such objects and use them as a place of permanent or temporary residence.

\section{Results and Discussion}

The reasons that encourage construction companies to build apartments instead of a multifamily dwelling are self-explanatory: simplified procedure for obtaining a building permit, absence of the need to change the type of permitted use of a land plot, absence of increased liability provided for by the Federal Law No. 214-FZ "On participation in shared construction of apartment buildings and other real estate objects and on amendments to some legislative acts of the Russian Federation" of 30.12.2004, absence of the need to create infrastructure characteristic of residential premises (schools, kindergartens, pharmacies, etc.). Perhaps this state of affairs could be tolerated for some time, but developers began to behave in bad faith violating the Russian competition law.

First of all, we are certainly talking about inappropriate advertising and actual deception of apartment buyers. Let us give one example: one of the decisions of Sverdlovsk OFAS Russia, according to which the declared inappropriate advertising contains untrue information "about the legal nature of the goods offered for sale - apartments of the lodging type in the hotel complex are offered as two-room apartments and three-room apartments in the residential complex since 
the advertising does not contain part of the significant information on the differences between the proposed housing for sale - apartments of the lodging type on the conditions of concluding a contract of participation in shared construction - from housing, which is denoted by the concept of "apartment" in the definition of the Housing Code of the Russian Federation and also on the differences in the rights of apartment and flat owners" [1].

S. Shcherbatova quite rightly notes: "In the acquisition of such a type of real estate as apartments, there are its pros and cons that each buyer must evaluate in relation to his personal situation" [2].

The reasons pushing citizens to purchase apartments are quite understandable: relatively low price of objects and often convenient location of the building with apartments for a working person.

However, the disadvantages that buyers of apartments receive are many times superior to the advantages of these objects associated with their price. The negative consequences of purchasing apartments instead of residential real estate include the following:

- purchased premises shall not comply with the requirements of the legislation for residential premises (noise insulation level, ceiling height, illumination level, etc.);

- inability to obtain preferential housing loans and participate in the "young family" program;

- lack of security of tenure as a result of the destruction of accommodation in emergency situations;

- lack of co-ownership right for common areas and land under the building;

- rates and standards for utility payments in apartments significantly exceed the fees for similar services in residential premises;

- inability to register at the place of residence and, as a result, the impossibility of exercising electoral rights and a number of social benefits (medical care, kindergartens and schools, etc.).

Despite the above circumstances, the real estate market continues to be filled with apartments.

According to I. Demidov: "The demand for apartments is growing, according to unofficial data in Moscow, more than 1000 transactions are made every month to buy apartments. Obviously, there is a significant replacement of residential premises with apartments, i.e. non-residential premises" [3].

The increase in the share of apartments in the real estate market, the absence of a legal definition of the concept of "apartments" lead to inexhaustible interest among researchers of civil and housing legislation in analyzing a number of issues related to the legal status of apartments, transactions with apartments, legal status of owners and users of such real estate.

In the absence of legal regulation of the turnover of apartments in the Russian Federation, the number of legal disputes related to apartments in the arbitration courts of the Russian Federation increases by an average of $30 \%$ compared to the previous year [4].

In these circumstances, a comparative legal analysis of the legal structure of premises built as apartments in the Russian Federation at present and residential premises seems timely and necessary.

In accordance with Article 15 of the Housing Code of the Russian Federation, an isolated building is recognized as residential, which is immovable property and suitable for permanent residence of citizens (meets the established sanitary and technical rules and norms, other requirements of the law). Thus, housing should, in the opinion of the legislator, meet three criteria: be suitable for permanent residence, be isolated and belong to the category of real estate, i.e. be so firmly connected with the land plot that it is impossible to move it without disproportionate damage to its purpose.

Legal periodicals have repeatedly studied the concept and characteristics of residential premises [5-12]. The criteria enshrined in the legislation are criticized and at the same time other ones are proposed. First of all, we are talking about the purpose for permanent residence and the legal recognition of premises as residential.

Let us dwell in more detail on the signs of residential premises in order to analyze the possibility of classifying apartments as residential premises.

Isolation as a sign of a living space means the isolation of a premise as a separate building or the isolation of a premise within the building with the presence of an independent (autonomous) exit from the premise to the adjacent land plot or to public places (stairwell, hallway of the apartment, etc.).

The relation of the premises to real estate means the close connection of premises (the building in which the premises are located) with the land plot (Article 130 of the Civil Code of the Russian Federation). In the scientific literature and in practice, it is now necessary to encounter the position that the category of real estate is ambiguous due to the fact that modern technical means allow any building to be moved from one place to another, without violating its structural elements and without damaging the purpose of the building being moved. However, the essence of real estate as a special category of civil law is still whether the object is capital and firmly connected to land in the sense that its movement is not carried out under normal conditions of turnover. In addition, it should be borne in mind that the reference to the classification of residential premises as real estate makes it possible to distinguish between the concepts of housing as such (in its constitutional, criminal law, criminal procedure) and housing as a special object of regulation of civil and housing legislation.

Suitability for permanent residence means compliance of the premises with sanitary standards and rules established by regulatory acts. The procedure for recognizing the premises as residential and the requirements that the premises must meet are established by the Decree of the Government of the Russian Federation No. 47 dated 28.01.2006. N.V. Kornilova quite fairly notes: "A residential building should be suitable for living during all seasons of the year, and not only in summer" [13, p. 4].

As noted above, in addition to these features, the literature also proposes a sign of the purpose of the premises for permanent residence. I.A. Drozdov 
connects the use of the term "intended" to distinguish between residential and non-residential premises, depending on the user's intentions. Thus, he proposes to limit to the sign of suitability, considering it objective, in contrast to the subjective category of "specificity" $[5, \mathrm{p}$. 11]. Here one should agree with the opinion of P.V. Makeev, critically evaluating this position: "Obviously, the purpose is subjective only at the stage of determining the customer's wishes for the object..." [8, p. 46]. A.V. Khaldeev, on the contrary, defines "specificity" as an objective feature - the objective property of a premise as a complex thing that is formed in the process of creating (construction or reconstruction) a premise and consisting of such characteristics that, in accordance with regulatory requirements, turn a premise into a residential facility [11, p. 114]. In fact, the premises are recognized as residential not because they are intended for permanent residence, but because they are residential.

Thus, the sign of premise specificity for living cannot be the basis for assigning apartments to residential or non-residential premises.

The sign of legal recognition of residential premises is not so often analyzed in the legal literature that it seems not entirely true. It is the registration of premises as residential on the basis of the requirements for residential premises, and in the manner provided for by regulatory acts that turn the premises into residential.

By analyzing all existing approaches in science, it can be concluded that residential premises are recognized as isolated, real estate, suitable for permanent residence and legally recognized as such (registered as residential).

The types of residential premises contained in a closed list are enshrined in Article 16 of the Housing Code of the Russian Federation. Types of accommodation have also been the subject of research in the legal scientific periodicals [5, 13-16]. These include rooms, apartments and residential buildings. According to the current regulatory acts of Russia, no other premises can be assigned to residential premises.

An apartment is a structurally separate facility in an apartment building providing direct access to public premises in such a house and consisting of one or more rooms, as well as auxiliary premises designed to satisfy citizens' domestic and other needs related to their living in such a separate facility. A residential building is an individually defined building consisting of rooms, as well as auxiliary premises designed to satisfy citizens' domestic and other needs related to their living in such a building (Article 16 of the Housing Code of the Russian Federation).

An apartment building, unlike a residential building, is not attributed by the legislator to the types of residential premises, which seems justified. In accordance with the Decree of the Government of the Russian Federation No. 47 of 28.01.2006, a combination of two or more apartments with independent exits either to a land plot adjacent to a residential building or to public premises in such a house is recognized as an apartment building.

A.A. Ivanov quite rightly notes that the only difference between an apartment and a residential building is the absence of apartments in the latter [14, p. 90]. In other words, a residential building consists of premises, although isolated, but not apartments.

As for the concept of apartments, there is no legal definition of apartments at the level of federal laws. In accordance with the Decree of the Government of the Russian Federation No. 1860 dated 18.11.2020, an apartment represents a hotel room of the highest category, which is part of an apartment hotel or apartment complex [26]. There are 4 types of apartments distinguished in literature: apartments, service apartments, apartment hotels and condo hotels [17, 18].

Thus, owing to the direct indication of the bylaw the apartments belong to a kind of hotel rooms and, respectively, cannot be considered from the legalistic point of view as premises. Despite this in legal literature the opinions on the legal structure of apartments were shared on two main points of view. Supporters are inclined to recognize apartments as premises [18, 19]. Also the opinion on the need to consider apartments as the latent form of housing built for various reasons instead of apartment houses is stated in the legal periodical press [27].

The opposite point of view about recognition of apartments as non-residential premises prevails in modern legal literature [2, 17, 20-23].

Actually apartments cannot be considered as a type of premises not only because, according to the direct indication of normative legal acts, they belong to the elements of hotel business. Apartments have no important sign of premises - legal recognition of the inhabited room.

Thus, apartments in the existing legal regulation cannot be included in housing stock per se. It is completely and utterly irrelevant how the owner calls the room - a palace, a small hut, a palazzo or an apartment. If an object is suitable for permanent residence, is isolated and these premises in the form of the apartment or a house belong to the real estate (on condition of the corresponding registration and inclusion in housing stock). If an object does not meet the specified signs, cannot be referred to a room, an apartment or a house, then it cannot be considered an object of the housing rights, irrespective of its name as "apartments" or somehow differently. Thus, on the basis of legalistic approach, the opinions on the inhabited nature of apartments, which are found in legal literature, seem groundless.

T.M. Patsiya fairly notes: “... the definition of the legal nature of apartments is not a certain problem which the Russian law did not face. Is that so that the incident with apartments is not in the same row with already resolved problem of recognition by premises of such objects as country and garden houses?.. if proceeding from intrinsic approach, then it is necessary to recognize apartments as premises if they correspond to the criterion of suitability" [19, p. 47].

The President of Russia V.V. Putin ordered the Government of the Russian Federation to make amendments on the legal status of "premises in multiuse buildings including used for the accommodation of citizens", i.e. to define the legal status of apartments 
until August 1, 2021 [24]. Proceeding from it either introduction into circulation of new category "the multiuse building with inhabited, non-residential and office premises", or emergence of objects with the name "apartments" not being premises, but with a possibility of accommodation and registration at the place of residence is in the short term possible.

On April 29, 2021 the draft federal law "On the introduction of amendments to the Town Planning Code of the Russian Federation and separate acts of the Russian Federation regarding regulation of the separate legal relationship arising in connection with the construction of multiuse buildings" is submitted to the State Duma of the Russian Federation [25]. The draft law assumes introduction of the concept of "multiuse buildings" - buildings consisting of inhabited and nonresidential premises, located outside the boundaries of the housing estate in a public and business zone, having provided separate criteria for location of such buildings as a part of territorial zones and the requirement to location of inhabited and non-residential premises in the building. It is respectively offered to extend the effect of the Housing Code of the Russian Federation to the relations connected with multiuse buildings.

The analysis of this draft law allows indicating its imperfection. The formulation offered in the draft law will cause certain discrepancies. Or any apartment house in which there is a shop, bank, pharmacy, etc. may be considered or recognized as the multiuse building, or only the buildings built "outside the boundaries of the housing estate in a public and business zone" will be recognized as such. The issues of town planning, reorganization and re-planning of premises in multiuse buildings, real and liability laws on these premises are irregularly resolved by the draft law; the specificity of the land plot under such buildings is not decided. The issues of taxation are not considered.

\section{Conclusion}

In conclusion it is worth pointing out that the changes offered in the legislation and amendments in general are unsystematic and require thorough completion if to consider them from the position of their need.

Besides, we consider that the current legislation needs only one new norm - the direct ban of further construction and realization of "apartments" as premises built in circumvention of the town-planning and housing legislation instead of apartments in apartment buildings.

\section{References}

1. Decision of Sverdlovsk OFAS Russia of 13.03.2017 with regard to case No. 143 (SPS Consultant Plus)

2. S. Shcherbatova, Apartments as housing? Housing law, 4, 33-48 (2019)

3. I. Demidova, Apartments, Housing law, 3, 59-65 (2021)

4. T.D. Polidi, E.V. Igumenov, Analysis of jurisprudence on issues related to apartments,
Property relations in the Russian Federation, 8, 6474 (2018)

5. I.A. Drozdov, The concept of residential premises, Law, 8, 9-17 (2006)

6. I. Kuzmina, The concept of housing, Russian Justice, 9, 29-30 (2001)

7. P.V. Krasheninnikov, Residential transactions. Comment on legislation (Moscow, 2001) 288 p.

8. P.V. Makeev, Role of the category of purpose in the definition of housing, Family and housing law, 6, 44-47 (2010)

9. A.A. Malakhova, Signs of residential premises in the light of the Housing Code of the Russian Federation, Lawyer, 10, 50-51 (2006)

10. V.V. Tuzhilov, The concept of residential premises, Civilist, 2, 69-73 (2009)

11. A.V. Khaldeev, Legal model of residential premises in the Housing Code of the Russian Federation, Journal of Russian Law, 8, 104-116 (2006)

12. Z.V. Chimov, The concept and characteristics of residential premises, Family and housing law, 4, 610 (2007)

13. N.V. Kornilova, Residential premises: concept, features and types, Housing law, 3, 3-9 (2007)

14. A.A. Ivanov, Real estate issues in the new Housing Code of the Russian Federation, Economy and law, 6, 87-99 (2005)

15. P.V. Makeev, Types of residential premises, Housing law, 4, 83-89 (2011)

16. Yu.P. Svit, Residential lease agreement, Housing Law, 3, 2-14 (2005)

17. A. Zhirov, Legal status of apartments: analysis of jurisprudence, Housing law, 12, 47-58 (2011)

18. E.F. Tsokur, Apartments: legal status, features, role in rental legal relations, Family and housing law, 5, 46-48 (2020)

19. T.M. Patsiya, Criteria for classifying premises as residential and the problem of apartments, Family and housing law, 4, 44-48 (2019)

20. O.G. Lazarenkova, E.V. Alekseeva, Some problems of determining the legal structure of apartments as a type of commercial real estate, Notary, 6, 29-32 (2020)

21. M.M. Monastyrev, Apartments, studios and lofts as temporary accommodation, Legislation and economy, 8, 51-59 (2015)

22. S.V. Savina, Turnover of apartments as housing: areas of improvement of legislation, Law, 4, 55-64 (2015)

23. A.L. Shilovskaya, Legal status of apartments, Legal issues of real estate, 2, 36-39 (2015)

24. Draft legislation on determining the status of apartments. Retrieved from: https://yandex.ru/turbo/ vz.ru/s/news/2021/1/18/1080607.html (date of access: 30.04.2021). 
25. Retrieved from: https://sozd.duma.gov.ru/bill/ 1162929-7\#bh_note (date of access: 30.04.2021).

26. Decree of the Government of the Russian Federation No. 1860 dated 18.11.2020; Collection of Legislation of the Russian Federation. No. 48. Art. $7721(30.11 .2020)$
27. T.D. Polidi, T.K. Baikova, E.V. Igumenov, Development of the apartment market as an example of inefficient urban planning policy, Property relations in the Russian Federation, 4, 68 (2016) 